\title{
JAKOŚĆ PRZEKŁADU W WARUNKACH KONKURENCJI RYNKOWEJ A KOMPETENCJE TŁUMACZA
}

DOl: http://dx.doi.org/10.12775/RP.2017.019

\begin{abstract}
Zarys treści: Jakość przekładu oraz jej ocena stanowią przedmiot ożywionej dyskusji zarówno w badaniach nad przekładem, jak i w praktyce tłumaczeniowej. Zwłaszcza w sytuacji rosnącej konkurencji na rynku usług tłumaczeniowych biura tłumaczeń starają się przekonać klientów do skorzystania ze swoich usług, podkreślając ich wysoką jakość. Artykuł stanowi próbę spojrzenia na jakość przekładu przez pryzmat norm jakości funkcjonujących w branży tłumaczeniowej. W artykule zostaną przedstawione kryteria zapewnienia jakości stosowane przez polskie biura tłumaczeń. Z uwagi na fakt, iż istnieje bezpośredni związek między kompetencjami tłumacza a jakością przekładu, zostanie podjęta próba określenia kompetencji, jakie są potrzebne zwłaszcza młodym tłumaczom, aby skutecznie konkurować na rynku usług tłumaczeniowych.
\end{abstract}

Słowa kluczowe: jakość przekładu, kryteria jakości przekładu, PN-EN 15038:2006, PN-EN ISO 17100:2015, kompetencje tłumacza

Defleksje dotyczące jakości przekładu rozumianej jako pytanie o dobry Mprzekład podejmowano już w okresie przednaukowym translatologii, gdy m.in. praktykujący tłumacze, głównie literaccy, filozofowie, filologowie i pisarze prezentowali własne przemyślenia związane z pracą nad przekładem (por. House 1998: 197; Dybiec-Gajer 2013: 19; Siever 2015: 2). W formułowanych 
wówczas aforystycznych i często metaforycznych wypowiedziach dominowały opinie mówiące ogólnie o niemożności tłumaczenia lub o niedoskonałości poszczególnych przekładów (por. Koller 2011: 28-29). Jako przykład można przytoczyć krótki wiersz niemieckiego poety Friedricha Hauga (1761-1829) „O złym tłumaczeniu”: „Czy tłumaczenie na niemiecki wyjdzie? - Nie wątpię, ponieważ każde zabójstwo wychodzi na jaw" (Haug, cytat za: Koller 2011: $30)^{1}$. Natomiast pierwsze publikacje, w których badacze w sposób zamierzony podejmowali problematykę jakości tłumaczenia, pojawiły się w latach 60 . XX wieku (por. Dybiec-Gajer 2013: 19).

Dziś zagadnienia jakości przekładu i jej oceny są obecne w dyskusji toczącej się zarówno w badaniach nad przekładem, jak i w ramach praktyki tłumaczeniowej. Choć wydaje się, że należą one do kluczowych problemów przekładoznawstwa, to w naukowej dyskusji - jak stwierdza Larisa Schippel nie odgrywają głównej roli (por. Schippel 2006: 7), a w polskiej myśli przekładoznawczej mają wręcz znaczenie marginalne (por. Dybiec-Gajer 2013: 23).

Według Joanny Dybiec-Gajer (2013: 34, 37-38) w przekładoznawstwie można wyróżnić dwa bieguny ujęcia jakości tłumaczenia, które łączy pogląd, iż jakość jest pojęciem stopniowalnym, gdyż w różnych ujęciach teoretycznych definiuje się ją jako stopień spełnienia pewnych norm czy standardów. Pierwsze ze wspomnianych stanowisk reprezentuje klasyczne podejście przekładoznawcze, wywodzące się z różnych tradycji i teorii przekładu wraz z tradycją krytyki literackiej. Drugi biegun, znacznie młodszy, wychodzący poza nurt tradycyjnych teorii przekładoznawczych, związany jest przede wszystkim z praktyką zawodową, zarządzaniem i ekonomią. Z uwagi na temat artykułu dalsze rozważania skupią się na tym ostatnim podejściu i będą dotyczyć jedynie tekstów pisemnych ${ }^{2}$ oraz wypływających stąd wniosków dla kształcenia kompetencji tłumaczy.

\section{Jakość w nurcie realizmu zawodowego}

Zjawiska współczesnego świata, takie jak globalizacja, związane z nią procesy migracji, ogromny postęp techniczny oraz kluczowa rola ekonomii i konieczność konkurowania na globalnym rynku, wpłynęły także na wykonywanie

\footnotetext{
${ }^{1}$ W oryginale: „Über eine schlechte Übersetzung Kommt die Verdeutschung wohl heraus? Ich zweifle nicht; Denn jeder Totschlag kommt an's Licht".

${ }^{2}$ Zagadnienie jakości, metodologii pomiaru oraz sposobach oceny jakości w przekładzie ustnym omawia Ewa Kościałkowska-Okońska $(2008,2009)$.
} 
zawodu tłumacza, a mianowicie przyczyniły się do jego technicyzacji i industrializacji (por. także Goudec 2007: 297):

Manufakturowy charakter jego [tłumacza - przyp. K. S.-K.] warsztatu przekształca się w sieciowy, technologiczny system procesowania tekstów (...). Tłumacz tekstów pisanych przestaje być indywidualistą, pracującym w zaciszu swojej pracowni ze słownikiem książkowym nad pojedynczym tekstem (...). Planowanie działań, a równocześnie dynamiczne i błyskawiczne zarządzanie własną działalnością upodabniają pracę - już nie indywidualnego tłumacza, ale raczej agencji tłumaczeniowych lub zespołu tłumaczy - do działalności przedsiębiorstw, dla których znaczenie mają koszt, tempo pracy i konkurencyjna jakość usługi (Piotrowska 2007: 7-8).

Stąd też w przekładoznawstwie rozwinął się nurt nazywany realizmem zawodowym lub profesjonalizacją kształcenia. Tłumaczenie jest postrzegane jako rodzaj działalności usługowej, która stała się branżą przemysłową (por. Dybiec-Gajer 2013: 21). Jednym z głównych założeń tego nurtu jest pogląd, że kształcenie tłumaczy powinno mieć charakter praktyczny i być dostosowane do wymogów i warunków przyszłej działalności zawodowej (por. Gouadec 2007: 165; Dybiec-Gajer 2013: 21). W takim ujęciu, podobnie jak w innych gałęziach gospodarki, jakość ma kluczowe znaczenie. Za miernik służący do jej oceny przyjmuje się natomiast głównie kryteria stosowane w zarządzaniu (por. Dybiec-Gajer 2013: 21). Trend ten doskonale ilustruje definicja terminu „ocena jakości” (ang. quality assessment) zaproponowana przez Chana Sin-wai: to „system zapewniający zachowanie właściwych standardów produkowanych towarów" (Sin-wai za Dybiec-Gajer 2013: 34). Również w doborze czynników mających wpływ na ocenę jakości przekładu można dostrzec wpływ nauk o zarządzaniu i praktyki zawodowej oraz podejścia biznesowo-rynkowego. Do czynników tych Chan Sin-wai zalicza bowiem m.in. nakład pracy, liczbę zaangażowanych tłumaczy, cenę, rolę zleceniodawcy/klienta, czas na wykonanie zlecenia (Sin-wai za Dybiec-Gajer 2013: 34).

W tym miejscu warto zauważyć, że definicja samego pojęcia jakości jest problematyczna zarówno w przekładoznawstwie (por. Dybiec-Gajer 2013: 37), jak i w zarządzaniu, z którego nurt realizmu zawodowego pojęcie to zaczerpnął (Gudanowska 2010: 161; Stoma 2012: 14). Jak podkreśla Monika Stoma (2012: 14), propozycji definicyjnych jakości jest tak wiele, jak wielu jest autorów i badaczy podejmujących tę problematykę. Wynika to głównie z jej złożonego i interdyscyplinarnego charakteru oraz odmiennej interpretacji. Poza tym niejednoznaczność definicyjna może także wynikać z powszechności użycia i późnego teoretycznego zainteresowania badaczy problematy- 
ką jakości (por. Stoma 2012: 14). Zapiski dotyczące problemu jakości można znaleźć już w dawnych przepisach prawnych, np. w Kodeksie Hammurabiego z XVIII wieku p.n.e., a także w starożytnej Grecji u Platona, który rozumiał ją jako pewien stopień doskonałości, i u Arystotelesa, który uważał ją za to, co sprawia, że rzecz jest rzeczą, jaką jest (por. Wawak 2006: 12; Gudanowska 2010: 162-163).

Również w przekładoznawstwie istnieje wiele koncepcji jakości, które obszernie omawia Joanna Dybiec-Gajer (2013: 38-45). Z zaprezentowanych koncepcji do nurtu realizmu zawodowego można zaliczyć następujące podejścia (por. Dybiec-Gajer 2013: 43-45):

\section{1) Jakość jako przydatność użytkowa („fitness for use”)}

Koncepcja ta jest popularna na rynku usług tłumaczeniowych. Jej założenia odpowiadają założeniom teorii skoposu, w której jakość rozumie się jako osiągnięcie zdefiniowanego celu tłumaczenia. Jednak cechą odróżniającą jest tutaj podejście typowo pragmatyczne, ekonomiczne i rynkowe: istotna jest skuteczność działania, a wszystko, co wykracza poza wymagania klienta, to marnotrawienie zasobów, tj. czasu i pracy tłumacza. Taki pogląd prezentuje także Daniel Gouadec (2007: 7), który stwierdza, że komunikat zawarty w tłumaczeniu powinien „zrealizować swój pierwotny cel (i nic więcej niż ten cel)"3.

\section{2) Jakość jako spełnienie wymagań klienta i zadowolenie klienta}

Koncepcja ta ma charakter typowo biznesowy. Najważniejszym elementem jakości w tym podejściu jest reakcja klienta i stopień jego zadowolenia, który mierzy się m.in. liczbą powtórnych zleceń oraz liczbą skarg i reklamacji. Satysfakcja klienta odgrywa kluczową rolę w pozyskaniu zaufania, zbudowaniu marki oraz w utrzymaniu pozycji rynkowej.

\section{3) Jakość jako rezultat dobrego procesu/dobrych praktyk}

Koncepcja ta zakłada, że do wykonania wysokiej jakości tłumaczenia niezbędna jest właściwa organizacja procesu tłumaczeniowego oraz zaangażowanie odpowiednich zasobów ludzkich. Aby zapewnić jakość procesu tłumaczenia, stosuje się systemy kontroli jakości oparte na określonych normach, standardach i certyfikacji, które dotyczą zarówno produktu tłumaczenia, jak i całego procesu świadczenia usług tłumaczeniowych. Do nich należą między innymi niemieckie normy DIN, amerykańskie SAE

\footnotetext{
${ }^{3}$ W oryginale: „(...) the message fulfils its initial purpose (and nothing but that purpose)”.
} 
i ASTM (w tym wytyczne dla usług tłumaczeniowych ASTM F2575-06 Standard Guide for Quality Assurance in Translation oraz ASTM F2089-01 - Standard Guide for Language Interpretation Services), norma europejska EN 15038:2006 (polska wersja PN-EN 15038) oraz normy Międzynarodowej Organizacji Normalizacyjnej ISO (np. norma, a właściwie specyfikacja techniczna dla projektów tłumaczeniowych ISO/TS 11669), w tym najnowsza norma EN ISO 17100:2015 (polska wersja PN-EN ISO 17100), która zastąpiła normę EN 15038:2006. Certyfikację zgodności pisemnych usług tłumaczeniowych $\mathrm{z}$ wytycznymi dotychczas obowiązującej normy EN 15038:2006 oferuje w Polsce BUREAU VERITAS POLSKA Sp. z o.o. oraz TÜV NORD Polska, a certyfikację zgodnie z obecnie obowiązującą normą EN ISO 17100:2015 oferuje w Polsce DEKRA. Warto w tym miejscu zwrócić uwagę na głosy krytyczne wobec takiego podejścia do jakości. Słusznie podkreśla się bowiem, że same systemy zapewnienia jakości i certyfikacje nie zapewniają wysokiej jakości przekładu, ponieważ głównym czynnikiem, od jakiego zależy jakość, jest człowiek: słaby tłumacz, który stosuje się do procedur, i tak wykona złe tłumaczenie (por. Gouadec 2007: 241). Poza tym niektóre normy zawierają wymagania, których nie sposób zrealizować w praktyce (por. Wilson 2012: 3). Na przykład model zapewnienia jakości organizacji Localization Industry Standards Association (LISA QA Model) określającej wymogi dla lokalizacji oprogramowania zawiera aż 46 kategorii, które dodatkowo umożliwiają dużą swobodę interpretacji (por. Wilson 2012: 3).

\section{4) Jakość jako wartość dodana}

Koncepcja ta ma charakter profesjonalno-biznesowy. Zakłada ona, że tłumaczenie wysokiej jakości podnosi wartość oferowanych produktów i usług, mogąc przyczynić się do umocnienia pozycji rynkowej oraz do zdobycia kolejnych rynków.

\section{5) Jakość jako rezultat kompetencji tłumacza}

Koncepcja ta zakłada, że tłumacz, który posiada odpowiedni zestaw umiejętności, zwany kompetencjami tłumacza, jest w stanie wykonać dobrej jakości tłumaczenie. Łączy się ona z koncepcją dobrych praktyk, ponieważ kompetentny tłumacz potrafi dobrze zorganizować pracę nad zleceniem tłumaczeniowym. W tym kontekście można więc stwierdzić, że połączenie jakości rozumianej jako rezultat kompetencji tłumacza z jakością rozumianą jako rezulatat dobrych praktyk może zapewnić wysoką jakość wykonywanych tłumaczeń. 
Biorąc pod uwagę przytoczone koncepcje jakości, w nurcie realizmu zawodowego postuluje się następujące kryteria jakości (por. Gouadec 2007: 6-8; Dybiec-Gajer 2013: 55-56):

- dokładność - zgodność tłumaczenia z faktami i ich interpretacją;

- sensowność - komunikat zawarty w tłumaczeniu musi mieć określone znaczenie w języku docelowym i jego kulturze;

- przystępność - tłumaczenie powinno być zrozumiałe dla każdego użytkownika, spójne, logiczne i dobrze zredagowane;

- skuteczność i ergonomiczność - tłumaczenie musi skutecznie przekazywać treść i spełniać określony cel;

- zgodność z dodatkowymi ograniczeniami, np. z językowymi i kulturowymi normami, konwencjami obowiązującymi w języku docelowym czy ze standardami terminologicznymi;

- zgodność z linią interesów klienta lub zleceniodawcy - tłumaczenie powinno realizować zamierzony cel (np. informować, przekonywać) i unikać skutków niepożądanych (np. irytacji użytkownika wynikającej z konieczności korzystania z niezrozumiałej instrukcji obsługi);

- efektywność i opłacalność - może np. oznaczać pominięcie w tłumaczeniu fragmentu tekstu wyjściowego czy dodanie informacji, które tłumacz uzna za istotne z punktu widzenia użytkownika tłumaczenia.

Aby tłumaczenie spełniało wyżej wymienione kryteria jakości, niezbędne jest stosowanie systemu zapewniania i kontroli jakości. Po transferze, czyli po zakończeniu procesu tłumaczenia, konieczne jest wdrożenie następujących procedur (Gouadec 2007: 24-25; Dybiec-Gajer 2013: 57):

- korekta (proofreading) - eliminacja rażących błędów (błędów gramatycznych, opuszczeń, niewłaściwego formatowania) i wskazanie tłumaczowi lub innej upoważnionej osobie oczywistych błędów, rozbieżności i błędów tłumaczeniowych; rezultatem korekty jest tekst poprawny pod względem językowym;

- redakcja (revision) - wszelkie operacje, które zmierzają do udoskonalania tekstu, tak aby spełniał on kryteria jakości oraz wszystkie wymagania określone dla tłumaczeń i sformułowane w specyfikacji zlecenia;

- postedycja (post-editing) - oznacza sprawdzanie, korektę i redakcję tekstu tłumaczenia sporządzonego automatycznie, np. wprowadzenie koniecznych zmian, tak aby tekst był zrozumiały lub spełniał kryteria jakości określone przez klienta, czy też poprawianie ustawień w celu wyeliminowania powtarzających się błędów. 
Omówione powyżej kryteria jakości tłumaczenia i procedury kontroli jakości uwzględniają także normy PN-EN 15038 i PN-EN ISO 17100.

\section{Normy dotyczące usług tłumaczeniowych i kompetencje tłumacza}

Norma EN 15038 „Usługi tłumaczeniowe - wymagania dotyczące świadczenia usług" przyjęta przez Europejski Komitet Normalizacyjny (CEN) w 2006 roku, stanowi pierwszą normę jakościową wyznaczającą standardy i procedury dla świadczenia najwyższej jakości usług w zakresie przekładu pisemnego. W 2015 roku zastąpiła ją norma EN ISO 17100 „Usługi tłumaczeniowe - wymagania dotyczące świadczenia usług tłumaczeniowych” opublikowana przez Międzynarodową Organizację Normalizacyjną. W przeciwieństwie do swojej poprzedniczki EN 15038, która jest uznana w 29 krajach Europy, EN ISO 17100 zawiera najważniejsze standardy dotyczące działalności tłumaczeniowej o ogólnoświatowym zasięgu. Adresatami są przede wszystkim podmioty działające na rynku tłumaczeniowym, tzw. dostawcy usług tłumaczeniowych (TSP, translation service providers), przede wszystkim duże biura tłumaczeniowe, a także indywidualni tłumacze prowadzący własną działalność gospodarczą oraz ich klienci. Zgodnie z art. 5 ust. 3 ustawy z dn. 12.09.2002 roku o normalizacji (Dz. U. z 2004 r. Nr 19, poz. 177 ze zmianami) stosowanie Polskich Norm jest co prawda dobrowolne, lecz w wypadku uczestniczenia $\mathrm{w}$ niektórych przetargach publicznych posiadanie certyfikatu zgodności z normą może być konieczne.

Jeśli chodzi o istotę norm, to obie są tzw. normami procesowymi. Nie zawierają one bowiem wytycznych dotyczących jakości tłumaczenia jako produktu, lecz opisują wymogi dla poszczególnych faz i elementów procesu tłumaczenia rozumianego szeroko jako świadczenie usług tłumaczeniowych. We wprowadzeniu do PN-EN ISO 17100 czytamy:

W niniejszej Normie Międzynarodowej określono wymagania dotyczące wszystkich aspektów procesu tłumaczenia, które mają bezpośredni wpływ na jakość i poziom świadczenia usług tłumaczeniowych. Dokument zawiera wytyczne dla dostawców usług tłumaczeniowych (TSP) w zakresie zarządzania podstawowymi procesami, minimalnych wymaganych kompetencji, dostępności zasobów i zarządzania nimi, a także innych działań niezbędnych do świadczenia usług tłumaczeniowych wysokiej jakości (PN-EN 17100, 2015: 4).

Wyżej wymienione normy regulują więc nie tylko sam proces tłumaczenia, lecz także inne związane $\mathrm{z}$ nim aspekty, określając wymagania w zakre- 
sie zasobów ludzkich, zasobów technicznych, systemu zarządzania jakością, zarządzania realizacją zleceń, relacji z klientem, procedur obowiązujących $\mathrm{w}$ świadczeniu usług tłumaczeniowych oraz w zakresie monitorowania i kontroli procesu tłumaczenia.

Z punktu widzenia kształcenia profesjonalnych tłumaczy najistotniejszy jest proces tłumaczenia. Dlatego też poniżej zostanie omówiona właśnie ta faza procesu świadczenia usług tłumaczeniowych. W obu normach proces tłumaczenia obejmuje sześć etapów, a mianowicie tłumaczenie, sprawdzenie, weryfikację, redakcję, korektę i kontrolę końcową, którą w najnowszej normie połączono $\mathrm{z}$ oddaniem tłumaczenia klientowi. $\mathrm{Z}$ tych sześciu faz aż pięć to różnego rodzaju czynności sprawdzające i weryfikujące, przy czym trzy z nich (sprawdzenie, weryfikacja oraz kontrola końcowa i oddanie tłumaczenia) są obowiązkowe. Położenie nacisku na czynności sprawdzające wskazuje jednoznacznie, że mają one zasadnicze znaczenie dla jakości dostarczanego produktu, zwłaszcza jeśli chodzi o język ojczysty, o czym tłumacze często zapominają. Potwierdzają to np. dane firmy Skrivanek sp. z o.o., jednego z największych dostawców usług tłumaczeniowych w Polsce. Wynika z nich, że 48\% wszystkich zastrzeżeń zgłoszonych w 2012 roku na jakość usług tłumaczeniowych to właśnie zastrzeżenia dotyczące tłumaczeń na język polski (por. Pluta, Krupińska-Matyka 2013).

Pierwszym etapem omawianego procesu jest tłumaczenie, które w nowej normie zostało doprecyzowane i zdefiniowane jako „zbiór procesów zmierzających do przekładu treści w języku źródłowym na treść w języku docelowym w formie pisemnej" (PN-EN ISO 17100 2015: 5). Dotychczasowe wymagania dotyczące tego etapu, obejmujące poprawność terminologiczną, gramatyczną, leksykalną, stylistyczną, zachowanie specyfiki kulturowej, formatowania oraz uwzględnienie odbiorców docelowych i przeznaczenia treści $\mathrm{w}$ języku docelowym, uzupełniono o wierność znaczeniową treści w języku docelowym (PN-EN ISO 17100 2015: 14). Drugą fazę stanowi sprawdzenie, którą wykonuje sam tłumacz i która polega na autoweryfikacji treści tłumaczenia w języku docelowym pod względem występowania błędów i opuszczeń. Sprawdzenie ma zapewnić także zgodność tłumaczenia ze specyfikacją. Po sprawdzeniu następuje weryfikacja polegająca na sprawdzeniu zgodności treści $w$ języku docelowym $\mathrm{z}$ treścią $\mathrm{w}$ języku wyjściowym i upewnieniu się, że „tłumaczenie jest zgodne z ustalonym przeznaczeniem” (PN-EN ISO 17100 2015: 15). Co istotne, weryfikację wykonuje nie tłumacz, lecz inna osoba, która posiada odpowiednie kompetencje w zakresie języka wyjściowego i docelowego. $\mathrm{Z}$ uwagi na to, iż sprawdzenie i weryfikacja stanowią obowiązkową fazę procesu, to wykonanie tłumaczenia zgodnego zarówno z normą 
PN-EN 15038:2006, jak i normą PN-EN ISO 17100:2015 wymaga zaangażowania minimum dwóch osób, tj. tłumacza oraz weryfikatora. Redakcja oraz korekta są usługami dodatkowymi, które wykonuje się na życzenie klienta. Redakcję zleca się redaktorowi specjaliście z danej dziedziny, który według nowej normy powinien posiadać odpowiednie kwalifikacje potwierdzone przez uczelnię wyższą i/lub doświadczenie w tej dziedzinie. Redakcję wykonuje się bez odwołania się do tekstu wyjściowego, żeby sprawdzić, czy tłumaczenie jest zgodne $\mathrm{z}$ ustalonym przeznaczeniem oraz czy jest merytorycznie poprawne i czy odpowiada obowiązującym konwencjom tekstowym i terminologicznym. Korekta natomiast to sprawdzenie ostatecznej wersji tekstu przed publikacją. Ostatni etap stanowi kontrola końcowa i oddanie tłumaczenia klientowi. Tutaj sprawdza się zgodność tłumaczenia ze specyfikacją.

Warto podkreślić, że norma odzwierciedla nie tylko koncepcję jakości jako procesu (jakość jako rezultat dobrych praktyk), lecz także koncepcję jakości jako rezultatu kompetencji tłumacza. Oznacza to, że do realizacji zlecenia tłumaczeniowego niezbędne są odpowiednie zasoby ludzkie, a kluczową rolę odgrywa tłumacz i jego umiejętności. Norma PN-EN ISO 17100 (2015: 10) precyzuje więc minimum kompetencji, jakie powinien posiadać profesjonalny tłumacz. Należą do nich: 1) kompetencje tłumaczeniowe, czyli zdolność wykonania tłumaczenia na odpowiednim poziomie zgodnie ze specyfikacją projektu oraz zdolność rozwiązywania problemów związanych ze zrozumieniem i tworzeniem tekstu; 2) kompetencje językowe i tekstowe w języku wyjściowym i docelowym, obejmujące zdolność rozumienia języka wyjściowego i biegłe posługiwanie się językiem docelowym oraz znajomość konwencji tekstowych; 3) kompetencje badawcze połączone z umiejętnością pozyskiwania informacji i ich przetwarzania, tj. zdolność skutecznego zdobywania dodatkowej wiedzy językowej i specjalistycznej koniecznej do zrozumienia tekstu w języku wyjściowym i do wykonania tłumaczenia; 4) kompetencje kulturowe, obejmujące m.in. znajomość norm zachowania, systemu wartości charakterystycznych dla kultur obu języków; 5) kompetencje techniczne, czyli m.in. umiejętność obsługi narzędzi, programów i systemów informatycznych wspierających proces tłumaczenia oraz - jako uzupełnienie kompetencji określonych w normie EN 15360 - 6) kompetencje dziedzinowe, polegające na zdolności rozumienia treści w języku źródłowym i odtworzenia jej w języku docelowym $z$ użyciem odpowiedniego stylu i terminologii.

Co ważne z punktu widzenia zapewnienia jakości, to zgodnie $\mathrm{z}$ nową normą nie tylko weryfikatorzy i redaktorzy, ale i tłumacze muszą obecnie udokumentować swoje kwalifikacje w dziedzinie, której dotyczy tłumaczenie. Dodatkowo wskazuje się wyraźnie na konieczność zapewnienia dostępu 
zarówno do nowoczesnych narzędzi wspomagających proces tłumaczenia, jak i do innych niezbędnych technologii (np. systemy zarządzania terminologią) oraz konieczność zapewnienia utrzymania i podwyższania kompetencji tłumaczy, weryfikatorów, redaktorów oraz innych pracowników m.in. poprzez organizowanie szkoleń. Poza tym proces tłumaczenia został uporządkowany i podzielony na chronologicznie następujące po sobie fazy: norma reguluje najpierw procesy i działania wstępne, następnie właściwy proces tłumaczenia, a na koniec działania po oddaniu tłumaczenia, mianowicie dokumentowanie i archiwizację informacji zwrotnej od klienta oraz samego projektu.

Zarówno norma EN 15360, jak i norma EN ISO 17160 doskonale odzwierciedlają technicyzujące zmiany zachodzące obecnie w przekładzie, polegające na jego rosnącej profesjonalizacji i presji rynku (por. Dybiec-Gajer 2013: 36). Wszystkie te zmiany znajdują odzwierciedlenie w badaniach podejmowanych w przekładoznawstwie oraz w dydaktyce przekładu. Jeśli chodzi o dydaktykę przekładu, warto zwrócić uwagę na to, iż wszystkie kompetencje wymienione $\mathrm{w}$ omawianych tutaj normach uwzględnia już europejski model kompetencji EMT, który został opracowany w 2009 roku z inicjatywy Dyrekcji Generalnej ds. Tłumaczeń Pisemnych (DGT), wewnętrznego serwisu tłumaczeniowego Komisji Europejskiej, na potrzeby stworzenia jednolitego europejskiego programu kształcenia tłumaczy pisemnych (European Master's in Translation) w ramach edukacji uniwersyteckiej.

Program EMT zakłada kształcenie „zawodowego tłumacza, eksperta w komunikacji międzyjęzykowej i multimedialnej" (EMT 2009: 1) i określa jego podstawowe umiejętności, które student powinien nabyć w trakcie studiów magisterskich realizowanych zgodnie z tym programem. Lista kompetencji obejmuje sześć umiejętności, tj. umiejętność świadczenia usług w zakresie tłumaczeń pisemnych (łącznie z zarządzaniem relacjami z klientami), umiejętności językowe i międzykulturowe (biegła znajomość języka źródłowego i docelowego, umiejętność streszczania tekstów oraz zdolność rozumienia informacji zawierających aluzje kulturowe), umiejętność wyszukiwania informacji (zdolność wyszukiwania informacji i krytyczne podejście do różnych źródeł informacji), umiejętności techniczne, zwłaszcza w korzystaniu z pamięci tłumaczeniowych i w zarządzaniu terminologią, umiejętności tematyczne (wiedza w dziedzinach specjalistycznych i jej zastosowanie w praktyce profesjonalnego tłumaczenia) (por. EMT 2009: 1).

Opisane w obu normach procedury procesu tłumaczenia oraz kompetencje tłumaczy zyskują na znaczeniu zwłaszcza w sytuacji rosnącej konkurencji na rynku usług tłumaczeniowych. 


\section{Zapewnienie jakości na rynku usług tłumaczeniowych w Polsce i kompetencje tłumacza}

Na przestrzeni ostatnich lat można zaobserwować wyraźny wzrost znaczenia roli usług tłumaczeniowych. Szacuje się, że w 2012 roku globalny rynek przekładów osiągnął wartość blisko 35 mld dolarów i rośnie w tempie kilkunastu procent rocznie („Inwestycje na polskim rynku tłumaczeń” 2016, http:// www.parkiet.com/artykul/1457775.html). Wiąże się to przede wszystkim z rozwojem nowych technologii IT i ze skutkami wspomnianej już globalizacji, do których należy postępująca migracja ludności, wzrost zagranicznych inwestycji i rosnąca liczba przedsiębiorstw działających nie tylko na rynku krajowym.

Według „Gazety Giełdy Parkiet” z 12 stycznia 2016 roku rynek tłumaczeń w Polsce rośnie i - jak wynika z prognoz na najbliższe lata - tendencja ta będzie się utrzymywać. Wartość tego rynku w Polsce przekroczyła już 1 mld złotych. W maju 2015 roku na Giełdzie Papierów Wartościowych zadebiutowała pierwsza spółka z branży tłumaczeniowej - Summa Linguae SA. W Polsce funkcjonuje obecnie 1500 profesjonalnych biur tłumaczeń, a przedmiotem działalności ponad 60 tys. podmiotów są usługi tłumaczeniowe. Świadczy to nie tylko o ogromnym zapotrzebowaniu na usługi tłumaczeniowe, ale także o głębokim rozdrobnieniu rynku. Większość z tych firm to jednoosobowe działalności gospodarcze, natomiast firm walczących o największe zlecenia publiczne i komercyjne jest zaledwie kilkadziesiąt. Podobna sytuacja panuje na rynku światowym, gdzie 100 największych podmiotów generuje tylko ok. $10 \%$ całego przychodu w branży (por. „Inwestycje na polskim rynku tłumaczeń" 2016, http://www.parkiet.com/artykul/1457775.html).

Do znanych firm działających na rynku polskim należą m.in. Agencja MAart Sp. z o.o., Bireta Professional Translations Kempińska \& Woźniakowska s.c., Centrum Lokalizacji CM Sp. z o.o. Sp. k., GET IT Sp. z o.o., ITAMAR Group Sp. z o.o., Letterman Sp. z o.o., Magit Sp. z o.o., mLingua Sp. z o.o., Quest Fior i Kiełtyka spółka jawna, SDL Language Translation \& Content Management Company, Skrivanek, Studio Gambit Sp. z o.o,. Summa Linguae Spółka Akcyjna, KONTEKST Spółka z ograniczoną odpowiedzialnością Sp. k. Większość z wymienionych firm jest zrzeszona w Polskim Stowarzyszeniu Biur Tłumaczeń (PSBT, http://www.psbt.pl/), które powstało 4 grudnia 2001 roku. Członkami założycielami było 11 firm tłumaczeniowych. Jednym z podstawowych celów PSBT jest promowanie wysokiej jakości usług świadczonych przez firmy członkowskie poprzez upowszechnianie dobrych prak- 
tyk i norm. Warto podkreślić, że PSBT odegrało kluczową rolę w opracowaniu i wprowadzeniu europejskiej normy tłumaczeniowej EN 15038:2006 na rynek polski. W 2006 roku jedna z firm członkowskich, Agencja MAart, przetłumaczyła normę na język polski i dokonała jej redakcji. Dzięki staraniom PSBT w 9 października 2006 roku Polski Komitet Normalizacyjny (PKN) opublikował tę normę w zbiorze norm polskich.

Według informacji zamieszczonych na stronie internetowej stowarzyszenia przedstawiciele PSBT stworzyli pierwszy na świecie system certyfikacji za zgodność z normą EN 15038, akredytowali w tym zakresie pierwszą firmę certyfikacyjną Bureau Veritas Certification Sp. z o.o. i przeszkolili audytorów, dzięki czemu polskie firmy jako pierwsze, już od początku 2007 roku, mogły poddać się procedurze certyfikacji za zgodność z normą EN 15038. W 2010 roku PSBT akredytowało i przeszkoliło audytorów firmy DEKRA, innej niezależnej firmy certyfikującej.

PSBT kładzie duży nacisk na zapewnienie jakości usług tłumaczeniowych. Członkowie PSBT przyjęli „Kodeks dobrych praktyk branżowych” i świadczą usługi zgodnie $\mathrm{z}$ europejską branżową normą dotyczącą usług tłumaczeniowych PN-EN 15038:2006. Ponadto wielu członków PSBT wdrożyło również normę jakości ISO 9001:2008. Według nowej normy PN-EN ISO 17100:2015 działają Agencja MAart Sp. z o.o. (http://www.maart.com/), Bireta Professional Translations Kempińska \& Woźniakowska s.c. (http:// www.bireta.pl/) i ITAMAR Group Sp. z o.o. (https://www.tlumaczenia.pl/). Posiadanie certyfikatu zgodności z tą normą świadczy o stosowaniu standardów jakości opracowanych specjalnie dla biur tłumaczeń ${ }^{4}$. Analiza informacji na temat zapewnienia jakości zamieszczonych na stronach internetowych 28 firm stowarzyszonych w PSBT wykazała, że najistotniejszymi elementami systemu zapewnienia jakości są procedury weryfikacji, korzystanie z nowoczesnych narzędzi wspomagających tłumaczenie oraz wykwalifikowani tłumacze.

Zgodnie $\mathrm{z}$ wytycznymi norm jakościowych faza weryfikacji przebiega przynajmniej dwustopniowo i obejmuje weryfikację tekstu tłumaczenia $\mathrm{z}$ oryginałem pod względem merytorycznym oraz weryfikację poprawności gramatycznej, składniowej i stylistycznej tłumaczenia. Centrum Lokalizacji CM (http://www.cmlocalization.pl/) realizuje procedurę weryfikacji aż $\mathrm{w}$ trzech etapach, a mianowicie wykonuje weryfikację maszynową $\mathrm{z}$ wykorzystaniem programu KeyStone ${ }^{\mathrm{mw}}$, umożliwiającego automatyczne wychwyce-

${ }^{4}$ Problem jakości usług tłumaczeniowych oferowanych przez biura tłumaczeniowe podjął także Lech Zieliński (2011: 120-122). 
nie typowych błędów interpunkcyjnych, pisowni wielkich liter, niespójności oraz niepoprawnego stosowania terminologii z bazy danych, korektę językową wykonywaną przez profesjonalnych korektorów oraz ostateczną kontrolę gotowego tekstu, przede wszystkim pod kątem poprawności formatu i prawidłowości wykonania usługi DTP.

Celem korzystania $\mathrm{z}$ nowoczesnych narzędzi wspomagających tłumaczenie, tzw. narzędzi CAT, jest zapewnienie spójności terminologicznej tłumaczonych tekstów. Chodzi tutaj o korzystanie z takich programów, jak: SDL Trados Studio, Wordfast, MemoQ.

Ostatnim $\mathrm{z}$ wymienionych elementów systemów zapewnienia jakości jest współpraca $\mathrm{z}$ profesjonalnymi tłumaczami. Letterman Sp. z o.o. (http:// www.letterman.pl/) na swojej stronie podaje na przykład, że zgodnie z zasadami normy współpracuje z tłumaczami spełniającymi określone kryteria, a mianowicie ukończone studia $\mathrm{w}$ dziedzinie tłumaczeń i 1 rok praktyki w zawodzie (lub 1000 przetłumaczonych stron), ukończone studia w innej dziedzinie i 2 lata praktyki w zawodzie (lub 2000 przetłumaczonych stron), w wypadku braku udokumentowanego wykształcenia wyższego 5 lat praktyki w zawodzie (lub 5000 przetłumaczonych stron). Zespół tłumaczy VIVALANG (http://vivalang.com.pl/) tworzą natomiast absolwenci uczelni kształcących tłumaczy - m.in. Katedry UNESCO do Badań nad Przekładem i Komunikacją Międzykulturową Uniwersytetu Jagiellońskiego czy European Masters in Conference Interpreting. Wielu z nich posiada akredytację instytucji unijnych.

\section{Podsumowanie}

Biura tłumaczeń starają się przekonać klientów do skorzystania ze swoich usług, podkreślając ich wysoką jakość, której zapewnienie ma gwarantować wdrożenie stosownych procedur oraz zapewnienie zarówno wykwalifikowanych tłumaczy i specjalistów, jak i odpowiednich zasobów technicznych. $\mathrm{W}$ świetle przeanalizowanych informacji zamieszczonych na stronach internetowych biur tłumaczeń zrzeszonych w Polskim Stowarzyszeniu Biur Tłumaczeń widoczna jest tendencja do podporządkowywania zawodu tłumacza wymogom międzynarodowych norm dotyczących jakości usług tłumaczeniowych. W związku z tym od tłumaczy oczekuje się całego wachlarza określonych kompetencji, tj. kompetencji tłumaczeniowych, kompetencji językowych i tekstowych w języku wyjściowym i docelowym, kompetencji badawczych i w zakresie pozyskiwania i przetwarzania informacji, kompe- 
tencji kulturowych, technicznych i dziedzinowych. Według obowiązujących norm umiejętności te mają zapewnić, że tłumacz będzie dostarczał usługi tłumaczeniowe wysokiej jakości. Takie oczekiwania oznaczają jednocześnie duże wyzwanie dla współczesnej dydaktyki przekładu. Celem ma być bowiem wieloaspektowe kształcenie przyszłych tłumaczy, umożliwiające zdobycie różnorodnych kompetencji zwiększających ich szanse na rynku pracy. Z drugiej strony perspektywy nie są optymistyczne, ponieważ technicyzacja $\mathrm{i}$ industrializacja usług tłumaczeniowych, jak i czysto ekonomiczne podejście, nakierowane na osiąganie zysków i skuteczności, narzucają także wymóg kształcenia odhumanizowanych profesjonalistów, trybików w machinie procesu dostarczania usług tłumaczeniowych, którzy mają stale optymalizować swoją pracę i przyczyniać się w ten sposób do zwiększenia zysków firm tłumaczeniowych działających w warunkach rynkowych. W tym kontekście odrębny problem stanowi poziom wynagrodzenia oferowanego przez biura tłumaczeń w ramach optymalizacji kosztów, który jest często nieadekwatny do stawianych wymogów kompetencyjnych. Pomijając jednakże tę kwestię, należy stwierdzić za Joanną Dybiec-Gajer, że „warto widzieć w uczącym się nie tylko potencjalnego przyszłego tłumacza, pracownika, »dostawcę usług tłumaczeniowych «, ale i indywidualnego człowieka z jego potencjałem i pasją, ale także ograniczeniami” (Dybiec-Gajer 2013: 271). Dlatego też dydaktyka przekładu, będąc dyscypliną humanistyczną, nie powinna ulegać presji rynku, lecz starać się łączyć podejście realizmu zawodowego z tradycją akademicką i filologiczną, ceniącą refleksję, kreatywność oraz krytyczne myślenie, a więc cechy, które w pracy profesjonalnego tłumacza są nie do przecenienia i okazują się równie ważne jak kompetencje określone w normach jakościowych.

\section{Literatura}

Dybiec-Gajer, J., 2013, Zmierzyć przekład? Z metodologii oceniania w praktyce przekładu, Kraków.

Gouadec, D., 2007, Translation as Profession, Amsterdam, Filadelfia.

Gudanowska, A. E., 2010, „Wprowadzenie do zarządzania jakością w przedsiębiorstwie produkcyjnym", [w:] Ekonomia i Zarządzanie, t. 2, nr 4, s. $161-170$.

House, J., 1998, „Quality of translation”, [w:] Routledge Encyclopedia of Translations Studies, M. Baker, K. Malmkjær (red.), Londyn-Nowy Jork, s. $197-200$. 
Koller, W., 2011, Einführung in die Übersetzungswissenschaft, Tübingen.

Kościałkowska-Okońska, E., 2008, Kryteria jakości w ewaluacji przekładu ustnego, „Rocznik Przekładoznawczy. Studia nad teorią, praktyką i dydaktyką przekładu”, E. Kościałkowska-Okońska, L. Zieliński (red.), nr 3-4, s. $105-116$.

Kościałkowska-Okońska, E., 2009, „Quality and criteria of its evaluation in conference interpreting”, [w:] Jakość i ocena tłumaczenia, A. Kopczyński, M. Kizeweter (red.), Warszawa, s. 64-75.

Piotrowska, M., 2007, Proces decyzyjny tłumacza, Kraków.

Pluta, M., Krupińska-Matyka, A., 2013, Sytuacja na rynku tłumaczeniowym $w$ Polsce, http://praca.interia.pl/news-sytuacja-na-rynku-tlumaczeniowym-w-polsce,nId,947138 (dostęp: 1 marca 2016 r.).

Schippel, L. (red.), 2006, Übersetzungsqualität: Kritik, Kriterien, Bewertungshandeln, Berlin.

Siever, H., 2015, Übersetzungswissenschaft. Eine Einführung, Tübingen.

Stoma, M., 2012, Modele i metody pomiaru jakości usług, Lublin.

Wawak, S., 2006, Zarządzanie jakością - teoria i praktyka, Gliwice.

Wilson, A., 2012, „Qualität ist das Gegenteil des Zufalls..., [w:] EUROCOM. TRANSLATE YOUR BIZ, kwiecień 2012, s. 3.

Zieliński, L., 2011, Egzamin na tłumacza przysięgłego a norma i jakość przekładu tekstów prawnych oraz prawniczych, „Rocznik Przekładoznawczy. Studia nad teorią, praktyką i dydaktyką przekładu”, M. Krajewska, L. Zieliński (red.), nr 6, s. 117-130.

\section{Źródła}

1. EMT 2009 = European Master's in Translation 2009, http://ec.europa.eu/ dgs/translation/ programmes/emt/network/documents/emt_factsheet_pl.pdf (dostęp: 4 marca 2016 r.).

2. „Inwestycje na polskim rynku tłumaczeń” 2016, [w:] Gazeta Giełdy Parkiet z dnia 12.01.2016 r., http://www.parkiet.com/artykul/1457775.html (dostęp: 2 marca 2016 r.).

3. PN-EN 15038 „Usługi tłumaczeniowe - wymagania dotyczące świadczenia usług".

4. PN-EN ISO 17100 „Usługi tłumaczeniowe - wymagania dotyczące świadczenia usług tłumaczeniowych”.

5. PSBT = Polskie Stowarzyszenie Biur Tłumaczeń, http://www.psbt.pl/ (dostęp: 2 marca 2016 r.). 


\section{Quality of translation in a competitive market and the translator's competence Summary}

The quality of translation and translation quality assessment are the subject of heated debates both in translation studies research and translation practice. Translation agencies try to convince clients to use their services and emphasise high quality of services provided, especially facing increasing competition in the translation industry. This article attempts to look at the quality of translation from the perspective of quality standards used in the translation industry. The paper will present quality assurance criteria applied by Polish translation agencies. Due to the fact that there is a direct relationship between the competences of the translator and the quality of the generated product, the article will seek to identify the competences necessary for beginning translators in order to effectively compete in the translation market.

Keywords: translation quality, quality criteria, PN-EN 15038:2006, PN-EN ISO 17100:2015, translator's competence

\section{(c) $\bigodot_{\mathrm{BY}} \bigodot_{\mathrm{ND}}$}

